\title{
REKONSTRUKSI PEMBELAJARAN MATEMATIKA DI ERA REVOLUSI INDUSTRI 4.0
}

\author{
Sumaryanta $^{1)}$, Agus Dwi Wibawa ${ }^{2)}$ \\ 1) PPPPTK Matematika, Sleman, DIY, maryanta01@gmail.com \\ 2)PPPPTK Matematika, Sleman,DIY, agusdwiwibawa@gmail.com
}

\begin{abstract}
Abstrak. Revolusi industri 4.0 menuntut dan mendorong reformasi pendidikan di berbagai negara, termasuk Indonesia. Perubahan cepat yang disebabkan hadirnya revolusi industri 4.0 membutuhkan penyesuaian di berbagai sendi kehidupan, termasuk bidang pendidikan. Pembelajaran matematika sebagai komponen kunci sistem pendidikan di Indonesia harus mampu diadaptasikan untuk menjawab tantangan kebutuhan belajar peserta didik yang selaras dengan dinamika perubahan oleh revolusi industri 4.0. Pembaharuan pembelajaran matematika adalah keniscayaan, esensial dan mendesak dilakukan. Pembelajaran matematika harus didesain dan dilaksanakan bagi pewujudan generasi baru yang siap menghadapi ketidakpastian dan perubahan yang terus berkelanjutan. Artikel ini dimaksudkan untuk menyajikan sebuah perspektif baru tentang rekonstruksi pembelajaran matematika di era revolusi industri 4.0. Artikel ini diharapkan dapat memberikan paradigma baru dalam melihat dan menyelenggarakan pembelajaran matematika ditengah-tengah arus perubahan di era revolusi industri 4.0.
\end{abstract}

Kata Kunci. rekonstruksi, pembelajaran matematika, revolusi Industri 4.0

\section{The Reconstruction Of Mathematics Teaching And Learning In The $4^{\text {th }}$ Industrial Revolution}

\begin{abstract}
The $4^{\text {th }}$ industrial revolution demands and encourages the educational reformation in many countries, including Indonesia. The rapid changes caused by the emergence of the $4^{\text {th }}$ industrial revolution require adjustments in various aspects of life, including education. Mathematics education as the key component of the education system in Indonesia should be adapted to answer the challenge of the student's needs in line with the dynamics changes at the $4^{\text {th }}$ industrial revolution era. Mathematical renewal and updates is a necessity, essential and urgent point to execute. The mathematics teaching and learning should be designed and implemented to prepare new generation facing continuous uncertainty and alteration. This article is intended to present a new perspective on the reconstruction of mathematics teaching and learning in the era of the $4^{\text {th }}$ industrial revolution. This article, as well, is expected to provide a new paradigm in viewing and organizing mathematics teaching and learning amidst the current changes in the $4^{\text {th }}$ industrial revolution era.
\end{abstract}

Keywords: reconstruction, mathematics teaching and learning, the $4^{\text {th }}$ Industrial revolution

\section{Pendahuluan}

Revolusi industri 4.0 merupakan salah satu isu paling kuat dalam perjalanan kehidupan manusia saat ini. Revolusi industri 4.0 merupakan terminologi yang berkaitan langsung dengan intervensi teknologi tingkat tinggi yang bertujuan tidak hanya mempromosikan tetapi secara drastis meningkatkan komputerisasi dan industrialisasi (Schwab, K.,2016, dalam 
Plessis, 2017: 10). Revolusi industri 4.0 yang ditandai adanya cyber dan kolaborasi manufaktur (Hermann et al, 2016, dalam (Afrianto, 2018:3) telah merubah hampir seluruh sendi-sendi kehidupan manusia. Revolusi industri 4.0 yang ditandai dengan kemajuan teknologi baru telah mengaburkan batas antara dunia fisik, digital, dan biologis (Hussin, A.A. (2018: 92). Revolusi industri 4.0 membawa perubahan mendasar pola dan tata kehidupan manusia. Cara-cara manusia dalam menjalani kehidupan mengalami pergeseran ekstrim akibat ketersediaan fasilitas hidup hasil revolusi industri 4.0.

Tidak saja dalam bidang industri, revolusi industri 4.0 telah berdampak luas di bidang akademik (Plessis, 2017: 9). Salah satu yang terdampak besar oleh revolusi industri 4.0 adalah bidang pendidikan (Hussin, A.A., 2018: 92). Pembaharuan pendidikan di era revolusi industri 4.0 merupakan tantangan sekaligus harapan baru bagi kontribusi pendidikan yang lebih signifikan untuk membangun peradaban manusia. Setiap komponen di bidang pendidikan harus berinovasi secara progresif agar pendidikan mampu mengambil tanggungjawabnya sebagai penopang sekaligus pembentuk peradaban manusia.

Pendidikan 4.0 adalah respon terhadap kebutuhan revolusi industri 4.0 di mana manusia dan teknologi diselaraskan untuk memungkinkan kemungkinan-kemungkinan baru (Hussin, A.A., 2018: 92). Revolusi industri 4.0 menuntut perubahan mendasar dalam konsep dan praktek pendidikan. Transformasi bidang pendidikan disebabkan antara lain adanya perubahan landscape kebutuhan tenaga kerja di masa datang, perubahan landscape teknologi, perubahan perilaku dan sikap peserta didik, dan perubahan landscape kebutuhan hidup manusia (Shahroom \& Hussin, 2018, 318). Hal ini merupakan tantangan sekaligus peluang yang dapat menempatkan pendidikan sebagai garda depan penjaga dan pembentuk peradaban manusia.

Tantangan revolusi industri 4.0 yang menuntut adaptasi bidang pendidikan, termasuk pendidikan matematika, antara lain disampaikan Shahroom \& Hussin (2018: 1) perubahan tren kebutuhan tenaga kerja, 2) perubahan dinamis bidang teknologi, 3) perubahan perilaku dan sifat peserta didik, dan 4) kebutuhan perubahan masa depan disebabkan isu dan masalah yang belum jelas terdeteksi saat ini. Berbagai landscape perubahan tersebut telah secara drastis mengubah struktur pekerjaan dan persyaratan keterampilan pekerjaan, dan tren ini diperkirakan akan terus berlanjut di masa mendatang (Janíková, Kowaliková, 2017: 72). Berdasarkan studi World Economic Forum tahun 2016 yang dilakukan pada Future Jobs, keterampilan yang yang dibutuhkan di lingkungan kerja industri 4.0 adalah: negosiasi, fleksibilitas kognitif, orientasi layanan, penilaian dan pengambilan keputusan, kecerdasan emosional, berkoordinasi dengan orang lain, manajemen sumber daya manusia, kreativitas, berpikir kritis, dan pemecahan masalah yang kompleks (Amiron, Latib, \& Subari, 2019: 487). Senada dengan itu, Helaludin dan Fransori (2019: 97) menyatakan bahwa di masa depan dituntut kesediaan sumber daya manusia yang mampu berpikir kritis dan memecahkan masalah, kreatif dan inovatif, mampu bekerja kolaboratif serta memiliki kemampuan komunikasi yang baik. Tentu hal ini harus diantisipasi bidang pendidikan sebagai sektor yang diandalkan untuk menyiapkan generasi masa depan.

Pembelajaran di sekolah diharapkan mampu mengembangkan empat keterampilan inti: keterampilan berpikir kritis dan pemecahan masalah, keterampilan komunikasi, kolaborasi keterampilan, dan kemampuan untuk menciptakan hal-hal baru (kreativitas) (Afrianto, 2018: 
9), tetapi sampai saat ini belum terwujud dengan baik. Pendidikan matematika yang sejatinya dapat menjadi inti dari proses penyiapan peserta didik dengan berbagai skill tersebut ternyata juga belum mampu memenuhi harapan dengan baik. Pendidikan matematika disinyalir masih terlalu terjebak para orientasi penguasaan materi, keterampilan-keterampilan teknis dan berhitung, belum berhasil mengembangkan berbagai keterampilan berpikir, yang sejatinya merupakan esensi dari belajar matematika itu sendiri.

Kekurangberhasilan pendidikan matematika mengembangkan keterampilan berpikir peserta didik, terutama keterampilan berpikir tingkat tinggi (HOTs) ditunjukkan oleh beberapa studi. Hasil studi PISA, dimana PISA memfokuskan penilaiannya pada kemampuan berpikir tingkat tinggi, capaian peserta didik Indonesia selalu rendah, jauh dibawah rata-rata peserta dari negara-negara lain (Sumaryanta, 2018: 102). Laporan Bank Dunia tahun 2018 tentang "World Development Report: Learning to Realize Education's Promise" menunjukkan bahwa capaian terbaik dari peserta didik Indonesia masih dibawah rata-rata negara-negara OECD (Organization for Economic Cooperation and Development). Hal ini menunjukkan bahwa dalam hal kemampuan berpikir tingkat tinggi peserta didik Indonesia kalah bersaing dengan peserta didik seusia dari negara-negara lain. Selain PISA, hasil studi internasional dari TIMSS (Trends in International Mathematics and Science Study) juga menunjukkan capaian belajar matematika peserta didik Indonesia masih rendah. Studi TIMSS tahun 2015 menunjukkan bahwa capaian matematika peserta didik Indonesia menempati peringkat 45 dari 50 negara. Seperti halnya hasil PISA, peserta didik Indonesia kesulitan menyelesaikan soal TIMSS disebabkan karakteristik soal TIMSS yang menguji pemahaman peserta didik, terutama jenjang berpikir tingkat tinggi. Secara nasional, rendahnya hasil belajar matematika dalam kaitannya dengan kemampuan berpikir tingkat tinggi dapat dilihat dari hasil ujian nasional yang menurun ketika sebagian soalnya adalah soal HOTs. Kebijakan pemerintah yang memasukkan soal-soal HOTs pada Ujian Nasional dalam tiga tahun terakhir disinyalir sebagai salah satu penyebab menurunnya hasil Ujian Nasional siswa (Sumaryanta, 2019: $555)$.

Berbagai kondisi di atas harus menjadi perhatian serius dari para pelaku pendidikan matematika. Pendidikan matematika harus dilakukan perbaikan sungguh-sungguh agar mampu menjadi instrumen yang mampu membantu penyiapan generasi Indonesia masa depan. Dalam konteks inilah diperlukan rekonstruksi pembelajaran matematika yang dapat menjadikan matematika mampu menjawab tuntutan kebutuhan pengembangan berbagai keterampilan yang sesuai dengan tuntutan masa depan. Rekonstruksi pembelajaran matematika diperlukan untuk mendorong pendidikan matematika menjadi lebih fungsional bagi kesiapan generasi Indonesia yang lebih kompetitif dan adaptif terhadap perubahan global kehidupan manusia.

\section{Rekonstruksi Pembelajaran Matematika}

Rekonstruksi pembelajaran matematika harus didasarkan pada visi baru dengan tata kelola yang lebih progresif, tidak hanya berfokus pada peserta didik menguasai materi matematika, tetapi mendukung kesiapan peserta didik dalam menghadapi peradaban baru. Rekonstruksi pembelajaran matematika tidak bisa dilaksanakan secara parsial dan sepotong-sepotong. Perubahan praktek pembelajaran matematika di kelas harus didukung dengan perubahan paradigmatik sejak dari visi pembelajaran matematika itu sendiri, sampai pada implementasi 
metodologi pembelajaran dan penilaian yang secara operasional dilaksanakan di kelas. Keterpakaian teknologi serta pemanfaatan masalah-masalah kontekstual yang dapat menghadirkan kebermaknaan pembelajaran juga sangat dipengaruhi visi pembelajaran matematika. Visi baru pembelajaran matematika tentu juga akan mempengaruhi keputusan pemilihan metodologi pembelajaran dan penilaian yang diterapkan di kelas. Perubahan praktek di kelas sebagai hasil dari pemilihan beragam metodologi pembelajaran dan penilaian serta pemanfaatan teknologi dan masalah-masalah kontekstual akan berdampak langsung pada hasil belajar peserta didik. Ketika peserta didik diharapkan menguasai berbagai skill yang dibutuhkan pada masa depan, maka visi pembelajaran matematika harus dirumuskan inline dengan itu, pemilihan metodologi pembelajaran dan penilaian harus dilakukan secara hati-hati agar mampu mewujudnyatakan visi yang ada, dengan didukung oleh pemanfaatan teknologi dan masalah-masalah yang lebih kontekstual. Kerangka pikir inilah yang mendorong dihasilkannya sebuah kerangka pembaharuan pembelajaran matematika yang sesuai dengan kebutuhan era revolusi industri 4.0.

Secara sederhana, rekonstruksi pembelajaran matematika di era revolusi industri 4.0 disajikan pada Bagan 1 berikut.

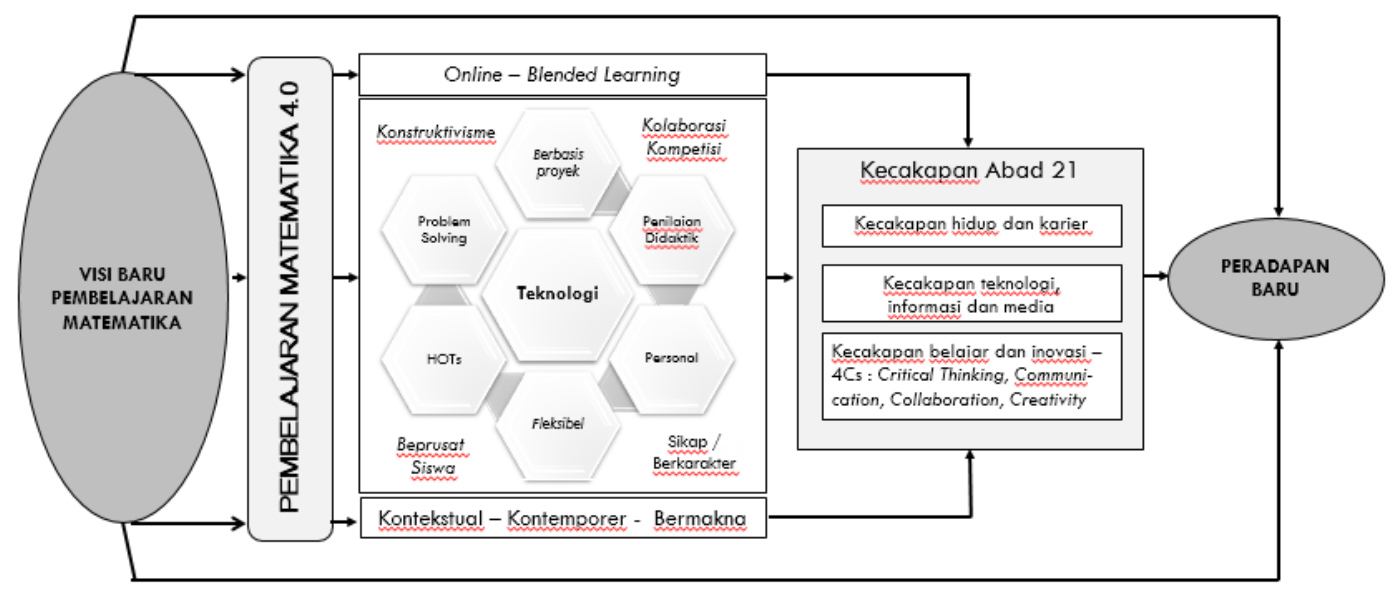

Bagan 1. Rekonstruksi Baru Pembelajaran matematika 4.0

Bagan 1 menunjukkan bahwa pembaharuan pembelajaran matetematika harus dilakukan secara komprehensif, baik dari sisi pembaruan visi, delivery system, maupun sistem penilaiannya. Tuntutan perubahan dan masa depan manusia berimbas pada kebutuhan pembaharuan pembelajaran matematika yang mampu memberikan manfaat optimal ketika peserta didik tersebut tumbuh dewasa dan mengambil tanggungjawab kemanusiaannya di masa depan. Metodologi pembelajaran harus dipilih yang inline dengan kebutuhan perwujudan visi baru pembelajaran matematika. Kesadaran tentang pembelajaran matematika yang bermakna menjadi keharusan dalam kelas-kelas pembelajaran di kelas. Optimalisasi teknologi, pembelajaran matematika dengan STEM, pembelajaran berbasis proyek, pembelajaran berbasis dan berorientasi problem solving, pembelajaran matematika kontekstual, pembelajaran dan penilaian HOTs, dan penguatan nilai-nilai kebaikan dalam pembelajaran matematika merupakan bagian penting dalam rekonstruksi pembelajaran matematika di era revolusi industri 4.0. Sistem penilaian juga harus ditata sedemikian 
sehingga bisa menjadi bagian dari instrumen mewujudnyatakan generasi baru manusia indonesia yang siap menghadapi tantangan zamannya.

Secara terinci penjelasan Bagan 1 tentang rekonstruksi baru pembelajaran matematika di era revolusi industri 4.0 diuraikan para point 2.1 sampai 2.8 berikut.

\subsection{Visi Baru Pembelajaran Matematika}

Pembelajaran matematika di era revolusi industri 4.0 membutuhkan visi baru yang selaras dengan tantangan dan kebutuhan kini dan masa depan. Pembelajaran matematika tidak bisa hanya terjebak pada nostalgia kebanggaan potensi dan kontribusi dirinya untuk pendidikan selama ini, tetapi harus menatap kebutuhan kehidupan di era revolusi industri 4.0, kemudian mengoptimalisasi diri dalam mendukung penyiapan SDM yang sesuai dengan kebutuhan, peluang dan tantangan. Matematika yang diajarkan di sekolah tidak cukup hanya berorientasi pada peserta didik untuk memahami konten keilmuan matematika, tetapi harus dapat menunjang terwujudnya insan dengan kecakapan sesuai tantangan abad 21, memiliki kecakapan hidup dan karier, kecakapan belajar dan inovasi, kecakapan informasi, media, dan teknologi, serta memiliki kemampuan berpikir kritis, komunikasi, kolaborasi, dan kreativitas. Berbagai kecakapan itu penting untuk kesiapan peserta didik mengarungi kehidupan di era revolusi industri 4.0.

Menurut Asmin (2008: 78), pembelajaran matematika selama ini masih memuat sejumlah kelemahan dan memerlukan orientasi baru untuk mendukung generasi Indonesia menghadapi tantangan masa depan. Kelemahan yang ada tidak dimaksudkan bahwa pembelajaran matematika yang telah berjalan secara mutlak dipersalahkan atau sama sekali tidak bermanfaat tetapi diperlukan suatu pembaharuan sebagai titik tolak perbaikan. Sesuai hakekatnya, matematika yang diajarkan harus mampu diposisikan secara tepat sesuai dengan: (1) arti/hakekat kependidikan yang berfungsi untuk mengembangkan kemampuan dan daya nalar serta pembinaan kepribadian siswa; (2) adanya kebutuhan yang nyata berupa tuntutan perkembangan riel dari kepentingan hidup masa kini dan masa mendatang yang senantiasa berorientasi pada perkembangan pengetahuan seiring dengan kemajuan ilmu dan teknologi. Orientasi untuk masa depan dan menjawab berbagai kebutuhan peserta didik sesuai dengan tantangan zamannya menjadi salah satu kunci penting bagi kontribusi signifikan pembelajaran matematika di sekolah.

Guru matematika sebagai bagian penting pendidikan matematika yang merupakan pemain vital dalam pembelajaran matematika perlu menyadari kembali bahwa pembelajaran matematika itu merupakan sub sistem dari sebuah proses menyiapkan peserta didik untuk masa depannya. Visi baru pembelajaran matematika seharusnya tidak lagi ke arah keterampilan yang sifatnya sekadar teknis dan prosedural. Pembelajaran matematika itu tidak cukup hanya sekadar mengajarkan materi dan kompetensi, tapi perlu diarahkan pada pengembangan berbagai kecakapan masa depan, seperti kecakapan hidup dan karier, kecakapan teknoligi informasi dan media, serta kecakapan belajar dan inovasi - 4C (critical thinking, communication, collaborative, creativity). Berbagai kecakapan tersebut penting untuk menyiapkan peserta didik hidup di masa depan. Guru-guru matematika harus mampu mengubah kelasnya menjadi wahana yang konstruktif bagi peserta didik untuk menyiapkan berbagai kompetensi yang mendukung masa depannya tersebut. 


\subsection{Optimalisasi Teknologi}

Teknologi di era revolusi industri 4.0 merupakan tantangan sekaligus berkah yang dapat difungsikan untuk mengoptimalkan pembelajaran matematika. Pembelajaran matematika harus mampu mengambil manfaat sebesar-besarnya pada perkembangan teknologi untuk menunjang keberhasilan pendidikan matematika. Teknologi menawarkan efektifitas, efisiensi dan daya tarik untuk pembelajaran (Putrawangsa \& Hasanah, 2018: 43). Pemanfaatan teknologi diyakini dapat mendorong pembelajaran matematika menjadi lebih aktif, produktif, dan menyenangkan (Supianti, 2018: 66). Penggunaan teknologi dalam pembelajaran matematika juga dapat memberikan dampak positif terhadap kemampuan penalaran, komunikasi matematis, pemecahan masalah, dan koneksi matematis peserta didik (Rahmawati, 2018: 381). Berbagai potensialitas teknologi tersebut dapat menjadi jawaban atas beberapa problematika dalam pembelajaran matematika selama ini.

Teknologi sebagai instrumen kunci pada revolusi industri 4.0 memberikan peluang besar bagi kebermanfaatannya untuk pembelajaran matematika. Berbagai software/aplikasi, Internet of Things (IoT), Virtual/ Augmented Reality, Artificial Intelligence (AI), Cloud Computing, dan lain-lain produk teknologi di era revolusi industri 4.0 merupakan peluang sekaligus tantangan dalam melakukan pembaharuan pembelajaran matematika. Teknologi tersebut telah secara nyata mengubah peradaban manusia, dan akan terus semakin meningkat dampaknya di masa yang akan datang, harus dapat dimanfaatkan secara positif untuk pembelajaran matematika. Selain itu, saat ini juga telah tersedia cukup banyak aplikasi yang sangat bermanfaat dalam pembelajaran matematika, misalkan geogebra, google classroom, quiziez, desmos, symbolab math solver, dan masih banyak yang lain. Keberadaan berbagai aplikasi tersebut memberikan peluang besar bagi guru dalam mengelola pembelajaran matematika di kelas dengan cara yang lebih efektif dan efisien sekaligus menyenangkan dan memberdayakan.

Tantangan bagi guru matematika tentu kesiapan guru dalam memahami dan menggunakannya sebagai instrumen untuk meningkatkan kualitas pembelajaran di kelas yang diampunya. Pemanfaatan beragam produk teknologi ini tidak hanya bermanfaat untuk memberikan hasil dan proses belajar yang lebih optimal, tetapi sekaligus menjadikan peserta didik familiar dengan teknologi (Rahmawati, 2018: 382). Pemanfaatan teknologi dalam pembelajaran matematika sekaligus menjadi wahana bagi peserta didik mengetahui dan merasakan keberadaan teknologi, sehingga mereka semakin welcome dan aware terhadap keberadaan dan kebermanfaatan teknologi.

\subsection{Pembelajaran Matematika dengan STEM}

Salah satu alternatif potensial untuk mengoptimalkan pemanfaatan teknologi dalam pembelajaran adalah melalui pembelajaran STEM. STEM adalah meta disiplin di tingkat sekolah dimana guru sains, teknologi, teknik, dan matematika mengajar pendekatan terpadu dan masing-masing materi disiplin dibagi-bagi tapi ditangani dan diperlakukan sebagai satu kesatuan dinamis (Brown, 2011). Pendidikan terintegrasi STEM juga dikatakan sebagai pendekatan yang mengeksplorasi pembelajaran di antara dua atau lebih bidang subjek STEM dan atau antara subjek STEM dengan mata pelajaran sekolah lainnya (Sanders, 2009). 
Integrasi teknologi dalam pembelajaran matematika memberikan peluang besar untuk lebih mengefektifkan pembelajaran matematika.

Banyak negara telah merasakan manfaat STEM: Amerika, Finlandia, Australia, Taiwan, Malaysia, Vietnam, dll (Winarni, J., Zubaidah, S., \& Koes H, S., 2016: 976). Penerapan STEM dalam pembelajaran dapat mendorong peserta didik untuk mendesain, mengembangkan dan memanfaatkan teknologi, mengasah kognitif, manipulatif dan afektif, serta mengaplikasikan pengetahuan (Farmawati, R., dkk., 2017: 200). Beberapa penelitian di Indonesia menunjukkan bahwa pembelajaran STEM dapat meningkatkan literasi sains, kreativitas, dan kemampuan memecahkan masalah (Permanasari, A., 2016: 23). Hasil-hasil penelitian tersebut perlu ditindaklanjuti dengan upaya kongkrit menerapkan pembelajaran STEM dalam kelas-kelas matematika. Potensialitas dalam pembelajaran STEM perlu lebih dieksplorasi agar pembelajaran matematika dapat mengambil manfaat yang optimal.

Pembelajaran STEM yang dilaksanakan di matematika dapat memfasilitasi peserta didik, tidak hanya menguasai konten keilmuan matematik, tetapi juga keterampilan berpikir matematik, seperti terlihat pada Bagan 2.

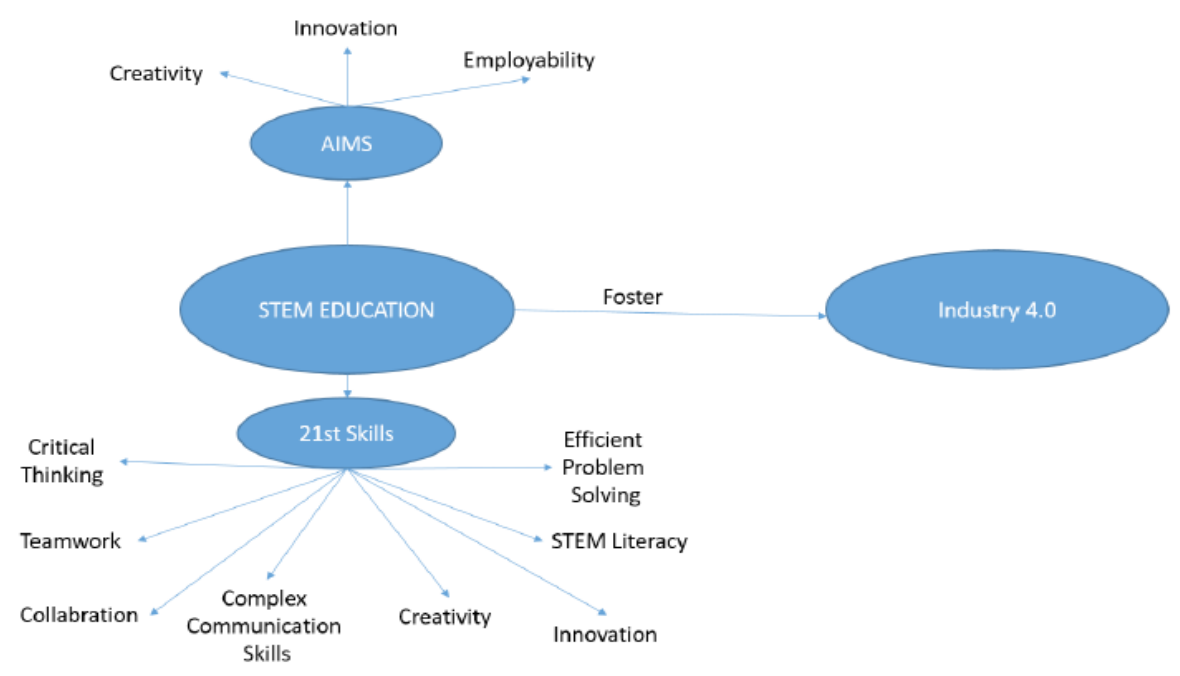

Bagan 2. Relationship Between STEM Education and Industry 4.0 (Idin, S., 2018: 203)

Bagan 2 menunjukkan betapa pembelajaran STEM memiliki sebaran manfaat yang luas. Penerapan pembelajaran STEM dalam matematika dapat mendorong pembelajaran matematika mengambil peran yang lebih besar dalam menyiapkan berbagai keterampilan yang dibutuhkan di abad 21 pada era revolusi industri 4.0 ini. Bahkan, kemampuan yang dapat dihasilkan melalui pembelajaran STEM seperti terlihat pada Bagan 2 di atas merupakan kemampuan-kemampuan yang penting disiapkan bagi peserta didik saat ini yang diharapkan dapat bermanfaat untuk kehidupannya di masa depan, masa dimana saat ini belum terlihat bentuknya, tetapi telah diidentifikasi kebutuhan kemampuannya, antara lain seperti yang disajikan pada Bagan 2. Hal ini tentu menjadi kesempatan bagi guru-guru matematika untuk dapat mendorong pembelajaran di kelasnya menjadi lebih bermakna, tidak 
saja bagi kepentingan peserta didik saat ini, tetapi juga untuk kesiapan mereka menjalani hidup di masa depannya.

\subsection{Pembelajaran Berbasis Proyek}

Pembelajaran berbasis proyek adalah pembelajaran yang dilaksanakan dengan memanfaatkan proyek untuk peserta didik (Thomas, 2010; dalam Aksela, M. \& Haatainen, O., 2018: 10). Pembelajaran berbasis proyek tidak terbatas pada memberikan siswa dengan pengetahuan konten, tetapi lebih jauh mengembangkan keterampilan dan sosial mereka, seperti mencari informasi dari sumber yang berbeda, berpikir kritis, menyelesaikan masalah, mengevaluasi diri, merangkum dan memberikan presentasi yang sangat direkomendasikan untuk pembelajaran seumur hidup (Phillips, et al. 1999; dalam Aldabbus, S. 2018: 72). Hal ini menempatkan pembelajaran berbasis proyek sebagai salah satu alternatif potensial diterapkan dalam pembelajaran matematika yang saat ini dituntut tidak sekedar mengajarkan konsep-konsep matematika tetapi juga menyiapkan peserta didik sebagai manusia kreatif, inovatif, dan adaptif terhadap perkembangan zaman.

Pembelajaran STEM berbasis proyek tentu menjadi salah satu altenatif menarik, seperti telah dijelaskan di atas, untuk mendorong pembelajaran matematika lebih fungsional bagi peserta didik. Tetapi tentu tidak hanya dengan STEM pembelajaran berbasis proyek dapat diimplemantasikan dalam pembelajaran matematika. Kompetensi matematika cukup banyak yang memungkinkan diberikan pada peserta didik melibatkan masalah autentik dan penugasan yang apabila dirancang dengan baik sangat potensial menjadikan pembelajaran matematika lebih efektif dan bermakna. Hal ini selaras dengan pendapat (Barron \& DarlingHammond, 2008; dalam Serin, H. 2019: 232) yang menyatakan bahwa pembelajaran berbasis proyek fokus pada mengeksplorasi masalah autentik dan melakukan tugas yang dirancang dengan baik.

Pembelajaran matematika berbasis proyek sangat selaras dengan kebutuhan untuk memfasilitasi peserta didik mengembangkan pengetahuan matematika sekaligus keterampilan berpikir. Hal ini selaras dengan pendapat (Schwartz, Mennin, \& Webb, 2001) yang menyatakan bahwa pembelajaran berbasis proyek berguna untuk membangun etos keterlibatan peserta didik dalam pembelajaran untuk pengembangan motivasi, pengetahuan dan keterampilan berpikir. Senada dengan itu, Mahmudi (2011: 1) menyatakan bahwa melalui pembelajaran berbasis proyek peserta didik memecahkan masalah kompleks yang mengharuskan peserta didik memiliki keterampilan dasar (membaca, menulis, dan matematika) dan keterampilan era digital (kerja tim, pemecahan masalah, pengumpulan data atau penelitian, manajemen waktu, mensintesis informasi, dan memanfaatkan alat teknologi tinggi). Hasil belajar matematika demikian yang merupakan kebutuhan penting pembelajaran di era revolusi industri 4.0 yang menuntut peserta didik difasilitasi untuk dapat mengembangkan kemampuan yang holistik.

\subsection{Pembelajaran Berbasis dan Berorientasi Problem Solving}

Matematika adalah salah satu komponen penting pendidikan, dan pemecahan masalah merupakan keterampilan kunci (Booker, 1993; dalam Akhter, N., Akhtar, M. \& Abaidullah, M., 2015: 2). Salah satu amanah pentingnya matematika diajarkan di sekolah adalah 
menfasilitasi pengembangan kemampuan pemecahan masalah. Pemecahan masalah yang juga dilihat sebagai keterampilan tingkat tinggi; dianggap sebagai jantung matematika (Halmos,1980; dalam Kolovou, 2011: 12). Pentingnya kemampuan penyelesaian masalah oleh siswa dalam matematika ditegaskan juga oleh Branca (1980; dalam Hadi \& Radiyatul, 2014:55), yaitu: 1) kemampuan menyelesaikan masalah merupakan tujuan umum pengajaran matematika, 2) penyelesaian masalah yang meliputi metode, prosedur dan strategi merupakan proses inti dan utama dalam kurikulum matematika, 3) penyelesaian masalah merupakan kemampuan dasar dalam belajar matematika.

Kebutuhan kemampuan pemecahan masalah di masa depan harus mampu dijawab pembelajaran matematika dengan pembelajaran berbasis dan berorientasi pemecahan masalah sebagai salah satu napas utamanya. Pemecahan masalah merupakan aktivitas kognitif yang paling signifikan dalam lingkungan sehari-hari dan profesional (Jonassen, 2000; dalam Kolovou, 2011: 20). Pemecahan masalah merupakan salah satu kemampuan kunci yang harus dipersiapkan bagi peserta didik saat ini untuk menghadapi kehidupannya di masa mendatang. Peserta didik perlu dibiasakan bertemu dan memecahkan masalah dengan tetap tidak melewatkan penguasaan keilmuan. Di sinilah tantangan bagi guru-guru matematika dimana peserta didik harus difasilitasi belajar keilmuan matematika sekaligus mengembangkan kemampuannya dalam pemecahan masalah.

Pembelajaran matematika berbasis problem solving merupakan kegiatan pembelajaran dimana masalah digunakan sebagai wahana utama dalam pembelajaran matematika. Masalah digunakan sebagai wahana peserta didik menguasai konsep matematika sekaligus mengembangkan keterampilannya dalam menggunakan konsep matematika dalam menyelesaikan masalah sehari-hari. Masalah tidak sekedar ditempatkan sebagai wahana untuk mengecek kemampuan peserta didik dalam mengaplikasikan konsep yang telah dipelajari, tetapi ditempatkan juga sebagai titik awal pembelajaran, seperti terlihat pada Bagan 3 berikut.

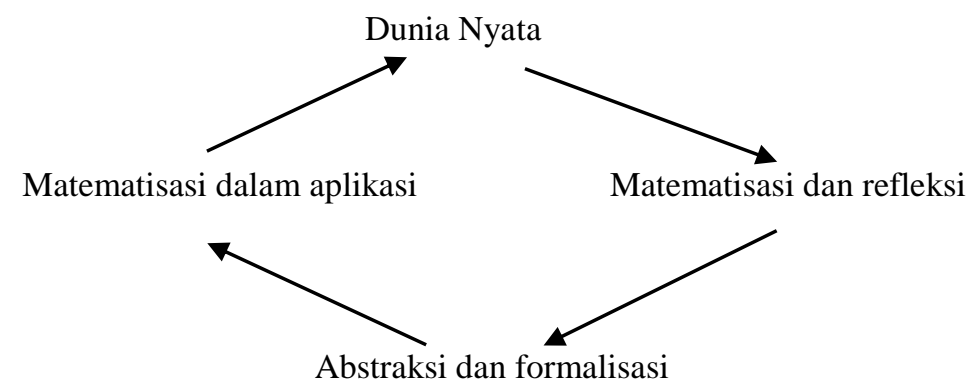

Bagan 3. Konsep Matematisasi (De Lange, 1987; dalam Siahaan, F.B., 2006: 37)

Bagan 3 menunjukkan betapa dunia nyata merupakan ruang luas sebagai wahana pembelajaran matematika. Tentu tidak hanya sebagai titik awal pembelajaran, tetapi masalah dapat juga ditempatkan sebagai orientasi dalam pembelajaran matematika. Pembelajaran matematika yang berorientasi pemecahan masalah adalah pembelajaran matematika yang menempatkan kemampuan pemecahan masalah sebagai kemampuan sasaran yang akan dicapai dalam pembelajaran. Pembelajaran matematika tidak semata-mata mengarahkan pembelajaran agar siswa dapat memahami konsep matematika dan aplikasinya, tetapi 
melalui pembelajaran matematika secara sengaja peserta didik difasilitasi untuk menguasai kemampuan pemecahan masalah. Kegiatan belajar matematika dijadikan wahana bagi peserta didik untuk mempelajari dan mengasah kemampuan pemecahan masalah, dimana kemampuan ini diharapkan nantinya dapat ditransferkan dalam kehidupannya sehari-hari dimasa depan.

\subsection{Pembelajaran Matematika Kontekstual}

Kata contextual berasal dari kata contex, yang berarti "hubungan, konteks, suasana atau keadaan" sehingga, contextual diartikan "yang berhubunagn dengan suasana (konteks)". Pembelajaran kontekstual dapat diartikan sebagai suatu pembelajaran yang berhubungan dengan konteks tertentu (Hosnan, 2014, dalam Hamruni, 2015: 178). Pembelajaran matematika di sekolah saat ini cenderung text book oriented dan kurang terkait dengan kehidupan sehari-hari siswa, serta cenderung abstrak, sehingga konsep-konsep akademik sulit dipahami, sehingga berakibat, hasil belajar matematika belum sesuai harapan (Harsa, 2016: 152). Pembelajaran matematika perlu lebih kontekstual agar kebermaknaan bisa dihadirkan selaras dengan perkembangan kehidupan manusia. Dinamika kehidupan manusia kontemporer di era revolusi industri 4.0 merupakan konteks yang potensial, tidak saja menjadikan pembelajaran matematika menjadi menarik dan bermakna bagi peserta didik, tetapi juga memfasilitasi peserta didik untuk dapat mengikuti dan mengantisipasi kehidupan masa kini dan masa depan.

Dalam pembelajaran matematika kontekstual, materi matematika disajikan tidak sekedar angka-angka tanpa makna, tetapi diberikan konteks yang dapat menjadi wahana materi matematika tersebut sampai pada peserta didik sebagai sesuatu yang memiliki arti dan keterkaitan dengan kehidupannya. Hal ini selaras dengan pemikiran menjadikan kehidupan sebagai sumber sekaligus orientasi pembelajaran matematika, seperti tersaji pada Bagan 4 berikut.

\section{A model of mathematical literacy in practice}

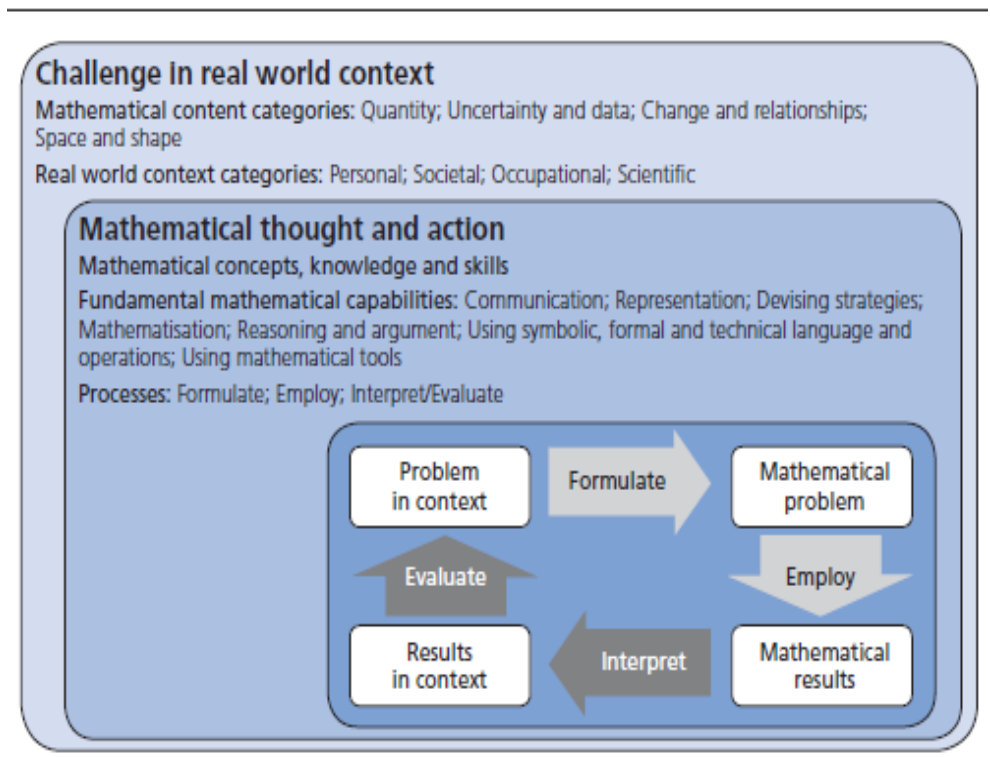

Bagan 4. Model terapan matematika dalam dunia praktis 
(Sumber: OECD, 2013)

Bagan 4 menunjukkan dengan jelas bagaimana permasalahan dalam konteks dapat diformulasikan sebagai masalah matematika kemudian diselesaikan menghasilkan temuan matematika dan diinterpretasikan sesuai konteksnya, dan pada akhirnya sampai pada pemanfaatannya untuk memecahkan masalah kontekstual. Masalah riil dengan data-data kongkrit akan mendorong peserta didik belajar seperti sedang menyelesaikan masalah hidup yang sesungguhnya sehingga lebih termotivasi menguasai konsep matematika yang ada pada masalah yang dipelajari. Konsep matematika yang dipahami akan tertanam lebih kuat di pikiran peserta didik karena proses tertemukannya konsep tersebut dilakukan melalui proses aktif peserta didik memecahkan masalah kontekstual. Setelah konsep dipahami dan kemudian diterapkan untuk memecahkan masalah kontekstual, selain lebih menguatkan pemahaman konsep, akan meningkatkan literasi peserta didik terhadap pemecahan kehidupan. Siklus pembelajaran matematika yang demikian akan menghadirkan pembelajaran yang kaya makna dan berdaya guna untuk mendukung peserta didik mampu menerapkan penguasaan matematikanya dalam kehidupan sehari-hari. Matematika akan dipelajari peserta didik sebagai sesuatu yang tidak sekedar angka-angka tanpa makna, tetapi kontekstual menyangkut masalah hidup sesungguhnya.

Penguatan pembelajaran yang berbasis problem solving dan berorientasi pada Higher Order Thinking Skill (HOTs) sangat krusial bagi terwujudnya SDM yang mampu berpikir kritis dan kreatif, inovatif sekaligus pemecah masalah. Pembelajaran matematika yang berbasis pada proyek juga penting didorong lebih kuat lagi sehingga mata pelajaran matematika tidak hanya membantu peserta didik memahami konten keilmuan matematika, tetapi juga mengembangkan daya inovasi dan kreativitasnya. Peserta didik perlu lebih dibiasakan menjadikan matematika sebagai akivitas, bukan sekedar angka-angka yang miskin makna.

Pembelajaran matematika juga perlu dikembangkan lebih fleksibel dan bersifat lebih personal, sesuai dengan perubahan perilaku dan sikap peserta didik. Saat ini dan dimasa yang akan datang setiap peserta didik akan memiliki sumber belajar tak terbatas dan berkualitas, sehingga mereka dapat menemukan dan menguasai sesuatu dari sumber manapun yang dapat diakses kapanpun dan dimanapun. Sistem pembelajaran matematika tidak boleh menyandarkan pada kepahlawanan guru sebagai sumber utama belajar, tetapi harus mentransformasi diri menjadi lebih terbuka dan adaptif terhadap ketersediaan tak terbatas sumber dan sarana pembelajaran. Pembelajaran matematika yang lebih mampu melayani kebutuhan belajar secara personal akan semakin mendorong percepatan kelahiran generasi baru untuk dunia baru di masa yang akan datang.

\subsection{Pembelajaran dan Penilaian HOTs}

HOTs merupakan terminologi yang mencakup beragam kemampuan berpikir, antara lain: kemampuan berpikir kritis, logis, reflektif, metakognitif, kreatif, pemecahan masalah tidak rutin, non-algoritmatik, analisis, evaluasi, mencipta, melibatkan "pembentukan konsep, pemikiran kritis, kreativitas/brainstorming, penyelesaian masalah, representasi mental, penggunaan aturan, penalaran, dan pemikiran logis, dan/atau membutuhkan pemikiran ke tingkat yang lebih tinggi daripada hanya menyatakan kembali fakta (Sumaryanta, 2018: 105). Kemampuan berpikir HOTs ini merupakan salah satu kompetensi penting dalam dunia 
modern, sehingga wajib dimiliki oleh setiap peserta didik (Widana, 2017). Pengembangan HOTs bagi peserta didik diharapkan menjadi salah satu komponen penting dalam pendidikan di era revolusi industri 4.0.

Selaras dengan tuntutan revolusi industri 4.0, salah satu reformasi pendidikan di Indonesia saat ini diwarnai dengan ditingkatkannya penerapan pembelajaran yang berorientasi pada HOTs dalam pembelajaran di kelas, termasuk dalam pembelajaran matematika. Mata pelajaran matematika merupakan salah satu "rumah" yang kondusif untuk berkembangnya kemampuan berpikir tingkat tinggi (Sumadyono \& Supinah, 2018: 9). Matematika sebagai ratu sekaligus pelayan ilmu memiliki potensi dan harapan besar untuk mengembangkan keterampilan berpikir HOTs peserta didik, apalagi untuk menyiapkan peserta didik memasuki masa depan yang dinamis sebagai dampak dari dinamika peradaban manusia.

Tidak hanya orientasi pembelajaran yang menyasar pada HOTs, penilaian dalam pembelajaran matematika diharapkan juga berorientasi pada pengukuran keterampilan berpikir HOTs peserta didik (Sumaryanta, 2018: 99). Setiap upaya melakukan pembaharuan sistem pendidikan harus disertai dengan pembaharuan sistem penilaian (Mardaphi, 2008: 5). Setiap usaha memperbaiki sistem pendidikan matematika tanpa disertai perbaikan sistem penilaian tidak akan dapat memberikan hasil yang optimal, bahkan mungkin akan sia-sia. Pembelajaran matematika yang berorientasi pada pengembangan keterampilan berpikir HOTs peserta didik menuntut sistem penilaian yang juga berorientasi pada penilaian terhadap keterampilan berpikir HOTs peserta didik. Setiap metode pendidikan matematika membutuhkan sistem penilaian yang berbeda (Van den Heuvel-Panhuizen, 1996). Oleh karena itu, penilaian HOTs perlu diterapkan untuk mendukung pengembangan HOTs pada pembelajaran matematika. Paket pembelajaran dan penilaian HOTs diharapkan dapat mendorong pembelajaran matematika sebagai instrumen penting untuk menyiapkan peserta didik menghadapi masa depannya.

\subsection{Penguatan Nilai-Nilai Kebaikan dalam Pembalajaran}

Perkembangan pesat dibidang teknologi merupakan peluang sekaligus ancaman bagi pembagunan peradaban manusia (Setiawan, D. 2018: 62), termasuk tentu pada masa revolusi industri 4.0. Sebagai peluang tentu perkembangan teknologi telah menghadirkan beragam kemudahan dalam kehidupan manusia. Akan tetapi apabila tidak disertai dengan semangat dan nilai-nilai kebaikan maka perkembangan teknologi dapat menghadirkan ancaman bagi kelangsungan hidup manusia. Teknologi yang ditemukan manusia dapat digunakan sebagai perusak sendi-sendi kehidupan yang membahayakan kelangsungan hidup manusia. Oleh karena itu, perkembangan kehidupan manusia di era revolusi industri harus disertai upaya sungguh-sungguh dalam mengembangkan nilai-nilai kebaikan dalam kehidupan.

Pendidikan di era revolusi industri harus mampu menjalankan fungsi yang holistik. Hal ini sebenarnya selaras dengan fungsi dan tujuan pendidikan di Indonesia seperti telah dirumuskan dalam UU No 20 Tahun 2003 tentang Sisdiknas yang menyatakan bahwa pendidikan berfungsi mengembangkan kemampuan dan membentuk watak serta peradaban bangsa yang bermartabat, mengembangkan potensi peserta didik menjadi manusia beriman dan bertakwa pada Tuhan Yang Maha Esa, berakhlak mulia, sehat, berilmu, cakap, kreatif, mandiri, dan menjadi warga negara demokratis serta bertanggung jawab. Pendidikan 
matematika sebagai salah satu komponen penting di bidang pendidikan dituntut mampu menjadi bagian penting dari proses penyemaian nilai-nilai kebaikan bagi peserta didik tersebut.

\section{Kesimpulan dan Saran}

Pembelajaran matematika sebagai bagian kunci sistem pendidikan di Indonesia tidak lepas dari kebutuhan pembaharuan agar mampu menjawab kebutuhan peserta didik saat ini dan masa depan. Rekonstruksi pembelajaran matematika diperlukan dan harus dilakukan secara komprehensif, baik dari sisi pembaruan visi, delivery system, maupun sistem penilaiannya. Ide-ide tentang pembelajaran matematika yang bermakna menjadi keharusan untuk diterapkan dalam pembelajaran matematika. Optimalisasi teknologi, pembelajaran matematika dengan STEM, pembelajaran berbasis proyek, pembelajaran berbasis dan berorientasi problem solving, pembelajaran matematika kontekstual, pembelajaran dan penilaian HOTs, dan penguatan nilai-nilai kebaikan dalam pembelajaran matematika merupakan bagian penting dalam rekonstruksi pembelajaran matematika di era revolusi industri 4.0. Penerapan pembelajaran tersebut akan memberikan sentuhan kebaruan yang lebih progresif bagi terwujudnya pembelajaran matematika yang lebih berdaya guna bagi peradaban manusia.

\section{Daftar Pustaka}

Afrianto. 2018. Being A Professional Teacher In The Era Of Industrial Revolution 4.0: Opportunities, Challenges and Strategies for Innovative Classroom Practices. English Language Teaching And Research Volume 2, No.1 Desember 2018: 1-13)

Aksela, M. \& Haatainen, O. 2018. Project-Based Learning (Pbl) In Practise: Active Teachers' Views Of Its' Advantages and Challenges. Conference paper: 5th International STEM in Education Conference Proceedings: Integrated Education for the Real World, At Queensland University of Technology, Brisbane, Australia, 21 $1^{\text {st }}$ to $23^{\text {rd }}$ November 2018

Akhter, N., Akhtar, M. \& Abaidullah, M. 2015. The Perceptions of High School Mathematics Problem Solving Teaching Methods in Mathematics Education. Bulletin of Education and Research, 37(1), p. 1-23

Aldabbus, S. 2018. Project-Based Learning: Implementation \& Challenges. International Journal of Education, Learning and Development, Vol.6, No.3, pp.71-79, March 2018

Amiron, E., Latib, A.B., \& Subari, K. 2019. Industry Revolution 4.0 Skills and Enablers in Technical and Vocational Education and Training Curriculum. International Journal of Recent Technology and Engineering (IJRTE), 8(1), Hal. 484 - 490

Angelianawati, L. 2018. Being An English Teacher in Industrial Revolution 4.0: An Overview About Roles, Challenges, and Implications. JDP 11 (3), p. 307-316

Asmin, A. Orientasi Baru Dalam Pembelajaran Matematika Sekolah. Paradikma Jurnal Pendidikan Matematika, 1(1), hal. 77 - 100.

Carl Jan du Plessis. 2017. A Framework for Implementing Industrie 4.0 in Learning Factories. Thesis presented in fulfilment of the requirements for the degree of Master of (Industrial) Engineering in the Faculty of Engineering at Stellenbosch University

Farmawati, R., dkk. 2017. Integrasi Problem Based Learning dalam STEM Education Berorientasi pada Aktualisasi Literasi Lingkungan dan Kreativitas. Prosiding Seminar Nasional 
Pendidikan IPA: STEM untuk Pembelajaran SAINS Abad 21. Palembang, 23 September 2017

Hadi, S. \& Radiyatul. 2014. Metode Pemecahan Masalah Menurut Polya untuk Mengembangkan Kemampuan Siswa dalam Pemecahan Masalah Matematis di Sekolah Menengah Pertama. EDUMAT Jurnal Pendidikan Matematika, Volume 2, Nomor 1, hlm 53 - 61

Hamruni. 2015. Konsep Dasar dan Implementasi Pembelajaran Kontekstual. Jurnal Pendidikan Agama Islam, Vol. XII, No. 2, Desember 2015, p. 177 - 188

Harsa, F.S. 2016. Integrasi ICT Dalam Pembelajaran Matematika. Jurnal Paedagogi, 8 (2), hal. 159162

Helaludin \& Fransori, A. 2019. Integrasi The Fours Cs Dalam Pembelajaran Bahasa di Era Revolusi Industri 4.0. Eduhumaniora: Jurnal Pendidikan Dasar, 11(2), hal. 95 - 106

Hussin, A.A. 2018. Education 4.0 Made Simple: Ideas For Teaching. International Journal of Education \& Literacy Studies. Vol 6, No. 3, p. $92-98$

Idin, S. 2018. An Overview Of STEM Education And Industry 4.0. Turkey: ISRES Publishing

Janíková, M. \& Kowaliková, P. 2017. Technical Education In The Context of The Fourth Industrial Revolution. R\&E-Source Journal, Special Issue, hal. 65 - 73

Kolovou. 2011. Mathematical Problem Solving in Primary School. Dissertation Utrecht University Netherlands.

Mahmudi. 2011. Project-Based Learning. Yogyakarta: Southeast Asian Ministers of Education Organization (SEAMEO) Regional Centre for Quality Improvement of Teachers and Educational Personnel (QITEP) in Mathematics

Mardapi, 2008. Teknik Penyusunan Instrumen Tes dan Nontes. Yogyakarta: Mitra Cendikia Offset

OECD (2013), PISA 2012 Assessment and Analytical Framework: Mathematics, Reading, Science, Problem Solving and Financial Literacy. OECD Publishing. http://dx.doi.org/10.1787/9789264190511-en

Permanasari, A. 2016. STEM Education: Inovasi Dalam Pembelajaran Sains. Prosiding seminar nasional pendidikan sains "Peningkatan Kualitas Pembelajaran Sains dan Kompetensi Guru melalui Penelitian \& Pengembangan dalam Menghadapi Tantangan Abad-21” Surakarta, 22 Oktober 2016

Putrawangsa, S. \& Hasanah, U. 2018. Integrasi Teknologi Digital Dalam Pembelajaran di Era Industri 4.0; Kajian dari Perpektif Pembelajaran Matematika. Jurnal Tatsqif, 16(1), hal. 42 - 54

Rahmawati, N.I. 2018. Pemanfaatan ICT Dalam Meningkatkan Kemampuan Literasi Matematika. PRISMA. Prosiding Seminar Nasional Matematika 1, https://journal.unnes.ac.id/sju/index.php/prisma/, hal. 381 - 387

Serin, H. 2019. Project Based Learning In Mathematics Context. International Journal of Social Sciences \& Educational Studies, Vol.5, No.3, p. 232 - 236

Setiawan, D. 2018. Dampak Perkembangan Teknologi Informasi dan Komunikasi Terhadap Budaya. Jurnal Simbolika, vol 4 No. 1, Hal. 62 - 72

Sumadyono \& Supinah. 2018. Pembelajaran Keterampilan Berpikir Tingkat Tinggi Berbasis UN Dan PISA. Yogyakarta: PPPPTK Matematika

Sumaryanta. 2018. Ragam Penilaian Pembelajaran Matematika. Yogyakarta: Smart Media

Supianti, I.I. 2018. Pemanfataan Teknologi Informasi dan Komunikasi (TIK) dalam Pembelajaran Matematika. MENDIDIK; Jurnal Kajian Pendidikan dan Pengajaran, 4(1), 63-70 
Shahroom, A.A. \& Hussin, N. 2018. Industrial Revolution 4.0 and Education. International Journal of Academic Research in Business and Social Sciences. Vol. 8, No 9, September 2018, 314 319

Van den Heuvel-Panhuizen. 1996. Assessment And Realistic Mathematics Education. Utrecht: Technipress, Culemborg

Winarni, J., Zubaidah, S., \& Koes H, S. 2016. STEM: Apa, Mengapa, dan Bagaimana. Prosiding Seminar Nasional Pendidikan IPA Pascasarjana Universitas Malang. 